\title{
Researchers urge boycott of supply company in labour dispute with warehouse employees
}

\begin{abstract}
Washington. The International Brotherhood of Teamsters Union has enlisted the support of scientists and physicians in a protracted labour dispute between Fisher Scientific of Pittsburgh, Pennsylvania, and 77 warehouse workers. The union is urging a boycott of products from Fisher Scientific until its members are rehired and their health-care coverage is restored.
\end{abstract}

The workers have been on strike since October 1991, when the company proposed a significant increase in the cost of their health-care insurance premiums. Union officials say that the company rejected a proposal by the union to take over the health plan, a step the union says would save the company at least $\$ 600,000$ over three years (the life of the worker's contract).

In February, the 77 workers were notified that they must accept the company's offer or lose their jobs permanently. The workers rejected the offer and, according to union officials, have since been locked out at the company's plant in Springfield, New Jersey. The plant serves as a major East Coast distribution point for Fisher Scientific, which has supplied the medical and scientific community with everything from chemicals and glassware to $\mathrm{pH}$ meters for 90 years.

In an open letter published in the 9 November issue of The Scientist newspaper, the ad hoc Physicians and Scientists for Justice for Fisher Employees urged Fisher Scientific "to rehire the 77 Springfield workers and to reinstate their health insurance". Union representatives say that the group has 120 members.

The company disputes the union's description of the events surrounding the strike. A spokesperson, Harry Schwalb, says that Fisher Scientific considered the union's proposal to run its own health plan, but when more information was requested, none was forthcoming. He also said that Fisher Scientific proposed a "reasonable increase" in the insurance premiums, but nothing approaching a three-year increase of 450 per cent claimed by the union. In addition to the soaring cost of health insurance in the United States, Schwalb said that the increase reflected the "unusually high claims experience" at the Springfield plant. Although Fisher Scientific would not elaborate on what was "reasonable" or why claims at the plant were "unusually high", Schwalb said that the proposal would bring the premiums of the 77 Springfield workers in line with those paid by the company's other 3,100 employees.

The company also refuted union claims that it had replaced skilled workers with unskilled workers. A picker or packer of orders is not required to have the same skills as the people who make electrochemical instrumentation or other precision equipment, Schwalb said.

Jonathan King, a professor of molecular biology at the Massachusetts Institute of Technology and a supporter of the campaign, hopes that his scientific colleagues will bring economic pressure to bear on the company by using alternative suppliers. "When a company whose profits come from a social concern for improved health decides to enhance its profit by cutting back on health insurance to a sector of its work force, then it's directly contradictory to the overall endeavour" [of providing the public with access to improved health care], King says.

In addition to involving researchers, the union has taken its case to sympathetic city officials. Last week, Boston City Council passed a resolution that would prohibit public institutions under the city's administration, including Boston City Hospital, from buying supplies from Fisher Scientific. The action awaits approval from the city's mayor, Raymond Flynn. Similar action is also planned for New York, the District of Columbia and Baltimore. "If we cut enough arteries, I believe we can win", says Ted Bloom, a union delegate. Diane Gershon

\section{Forthcoming space launch rekindles debate in Brazil}

São Paulo. The scheduled launch next month by a US company of the first satellite built by Brazil has renewed debate over the direction of the Brazilian space programme. On the one hand, there is a feeling that the government has not done enough to support a civilian space programme and that it is more interested in saving money than in getting results. On the other hand, there is concern elsewhere that an indigenous capacity to launch future satellites could also be used to develop military weapons:

The Data Collecting Satellite (SCD-1), which arrived in the United States earlier this month, is being prepared for launch on 12 December from Florida atop the Pegasus rocket built by the Orbital Sciences Corporation of Fairfax, Virginia. The 50-foot winged vehicle is sent into orbit from an aircraft and can carry a payload of up to 450 $\mathrm{kg}$. The 115-kg Brazilian satellite will be used to gather real-time meteorological data from automated ground stations and relay them to a control centre.

The Brazilian satellite will be only Pegasus's third launch. The rocket made its first flight in 1990, and its second launch placed a US payload into the wrong orbit. Although Brazilians are relieved that a mission originally set for 1986 seems at last ready to go into orbit, some scientists are unhappy that the government did not choose a more tested rocket such as LTV's Scout, which last weekend successfully launched a military payload. It is thought that the low overall cost of the launch, US\$14 million, played a significant role in the government's decision.

At the same time, critics say that the government should have made a more favourable arrangement. José Monserrat Filho, an adviser on space policy to the Brazilian Society for the Progress of Science, says that the former Soviet Union was prepared to transfer space technology as part of an arrangement to use Kosmos, a Russian launch vehicle, and that an important opportunity to strengthen the country's rocket programme was lost by choosing a company that did not offer such benefits.

The original plan was to launch four small satellites built by the civilian National Institute of Space Research (INPE) and launched by a vehicle developed by the Air
Force. But the United States and other countries have raised objections for fear that the technology would also be applied to military payloads, in particular ballistic missiles (see Nature 339, 164 \& 329; 1989). The strong ties between Brazilian weapons manufacturers and countries such as Iraq added to international concern.

The difficulties in obtaining the necessary equipment and technology have delayed the project, forcing the government to choose Pegasus for the SCD-1, which has been ready for more than a year. The satellite cost US\$20 million to build.

Although officials, including José Israel Vargas, the new minister for science and technology, smiled happily as the satellite was packed up for its trip, the fate of the Brazilian space programme remains uncertain. The new government of Itamar Franco, who replaced Fernando Collor de Mello as president after Collor's impeachment, has not yet taken a position on Collor's plan to create a single space agency. But most scientists would like to see it be placed under civilian control, as are the US and European space agencies.
Ricardo Bonalume 